\title{
Okul Öncesi Dönemde Çocuğu Olan Babaların Baba Çocuk İlişkileri ve Babalık Rolü Algıları Arasındaki İlişkinin İncelenmesi: Gaziantep İli Örneği ${ }^{1}$
}

\author{
Hilal GÜZEL \\ Milli Eğitim Bakanlığı, Gaziantep / Türkiye, \\ hilalguze116@gmail.com, ORCID: 0000-0001-8958-8434 \\ Doç. Dr. Aysel TÜFEKCI* \\ Gazi Üniversitesi, Temel Eğitim Bölümü, Okul Öncesi Eğitimi Anabilim Dalı, Ankara / Türkiye, \\ atufekci@gazi.edu.tr, 0000-0001-7792-5624
}

\section{$\ddot{O} z$}

Araştırmanın amacı, okul öncesi dönemde çocuğu olan babaların babalık rolü algıları ile baba çocuk ilişsisi arasındaki ilişkinin incelenmesidir. İlişkisel tarama modelinde desenlenmiş olan araştırmanın örneklemi 3-6 yaş grubunda çocuğu olan ve araştırmaya gönüllü olarak katılan 1015 babadan oluşturulmuştur. Araştırma verileri 20182019 eğitim öğretim yılında, Kişisel Bilgi Formu, Çocuk Ebeveyn İlişki Ölçeği Baba Formu ve Babalık Rolü Algı Ölçeği kullanılarak toplanmıştır. Verilerin analizinde Mann-Whitney U Testi, Kruskal-Wallis H Testi ve Spearman Korelasyon Testi kullanılmıştır. Araştırma sonucuna göre, babaların Babalık Rolü Algı Ölçeği puanlarının

\footnotetext{
${ }^{1}$ Çalışma birinci yazarın ikinci yazar danışmanlığında yürütmüş olduğu yüksek lisans tez çalışmasından üretilmiştir. Gaziantep İl Milli Eğitim Müdürlüğünden araştırma verilerinin toplanması için gerekli izinler ve veri toplama araçlarının kullanım izinleri alınmıştır.

* Sorumlu Yazar. Tel: +90 3122021739

Makale Tarih Bilgisi. Gönderim: 19.04.2020, Kabûl: 06.07.2020, Erken Görünüm: 16.04.2021, Basım: Aralık, 2021

(C) 2021. Kalem Eğitim ve Sağlık Hizmetleri Vakfı. Bütün Hakları Saklıdır. ISSN: 2146-5606, e-ISSN: 2687-6574.
} 
anne baba öğrenim düzeyi, anne baba yaşı, anne baba mesleği, gelir, algılanan sosyoekonomik düzey, ilk baba olma yaşı, aile yapısı, çocuk sayısı ve çocuk yaşına göre anlamlı farklılık gösterdiği görülmüştür. Ayrıca, babaların Babalık Rolü Algı Ölçeği puanları ile Çocuk Ebeveyn İlişki Ölçeği puanları arasında negatif yönde, orta düzeyde anlamlı bir ilişki olduğu görülmüştür.

Anahtar Kelimeler: Okul öncesi dönem; Babalık; Babalık rolü algısı; Baba çocuk ilişkisi; Toplumsal cinsiyet.

\title{
Examination of the Relationship Between Fathers'
} Relationships with Their Children and Their

\section{Fatherhood Role Perceptions: The Case of Gaziantep}

\begin{abstract}
The aim of this research is to investigate the relationship between fatherhood role perception of fathers who have children at preschool age and their relationship with their children. The sample of the research which is designed in relational survey model is composed of $1015 \mathrm{fa}-$ thers who have preschool age children and who volunteered to participate in the study. The data were collected during the 2018-2019 academic year using Personal Information Form, Child Parental Relationship Scale Father Form, and Fatherhood Role Perception Scale. Data were analyzed using Mann-Whitney U Test, Kruskal-Wallis H Test, and Spearman Correlation Test. According to the results, it was found that the participating fathers' scores on the Fatherhood Role Perception Scale varied by parental education level, parental age, parental profession, income, perceived socioeconomic level, age of being father for the first time, family structure, number of children, and children's age. In addition, a negatively and moderately significant relationship was found between the Fatherhood Role Perception Scale scores and Child Parental Relationship Scale scores of the fathers who participated in the study.

Keywords: Pre-school period; Fatherhood; Fatherhood role perception; Father child relationship; Gender.
\end{abstract}

\section{Extended Summary}

\section{Purpose}

In modern society the concept of fatherhood and fatherhood roles and responsibilities have started to be questioned and reconceptualized (Aktürk, 2015; Bayer, 2013; Chin, Hall, and Daiches, 2011; Crespi and Ruspini, 2015; Czymoniewicz-Klippel, 2019; Dempsey and Hewitt, 2012; Dick, 2011; 
Eggebeen and Knoester, 2001; Johansson, 2011; Zeybekoğlu, 2013). Hovewer, the fact that mothers are still the main target group in research on parenting (Mercan and Tezel-Şahin, 2017; Tezel-Şahin and Özyürek, 2016) and that in Turkey, research conducted with fathers lag behind those conducted with mothers (Mercan and Tezel-Şahin, 2017) is noteworthy. Therefore, the aim of this study is to examine the relationship between fathers' fatherhood role perceptions and their relationship with their preschool age children.

\section{Method}

The research was designed in relational survey model. The sample of the study consists of 1015 fathers who have preschool age children. Data were collected during the 2018-2019 academic year by using Personal Information Form, Fatherhood Role Perception Scale and Child Parental Relationship Scale. Because the data did not meet the normal distribution assumptions, the data were analyzed using Mann-Whitney U Test, Kruskal-Wallis H Test and Spearman Correlation Test.

\section{Results and Discussion}

As a result of the study, it was found that the fathers' fatherhood role perceptions varied by education level of fathers and mothers. The higher the level of education, the higher the fathers' scores and that they had a more positive fatherhood role perception. This finding overlaps with the findings in the literature (Aksoy and Tatlı, 2019; Kuruçırak, 2010; Poyraz, 2007; Şahin and Demiriz, 2014; Telli, 2014; Türkoğlu and Gültekin-Akduman, 2015a, 2015b; Zeybekoğlu, 2013).

Regarding fathers' age variable, it was found that 31-35 years old and 36-40 years old fathers scored higher while 26-30 years old fathers scored lower than 31-45 years old fathers. In the relevant literature there is inconsistency regarding the age of fathers. In some studies, it was stated that the young fathers' fatherhood role perceptions were more positive (Seçer, Çeliköz ve Yaşa, 2007) while some of the studies did not show any significant differences in terms of paternal age variable (Aksoy and Tatl, 2019). As the maternal age were examined, it was found that the fathers whose spouses were between 21-25 years old had a more negative fatherhood role perceptions. This finding is in line with the findings obtained in Türkoğlu and Gültekin-Akduman (2015b). 
Regarding parental occupation status, it was found that the fathers who are civil servants have a more positive fatherhood role perceptions than those in other occupational groups. It was also found that fathers who are unemployed or are laborer have more negative fatherhood role perceptions than those in other occupational groups. These findings are in line with previous studies (Karadayı, 2001; Kuruçırak, 2010; Poyraz, 2007; Telli, 2014). Regarding occupational status of mothers, it was found that the fathers whose spouse is a civil servant had a more positive fatherhood role perceptions. In addition, fathers have a more negative fatherhood role perceptions when the mother was unemployed. These findings coincide with the findings of previous studies (Kuruçırak, 2010; Türkoğlu and Gültekin-Akduman, 2015a). Regarding monthly income variable, it was found that high-income fathers have more positive fatherhood role perceptions while those with low income have more negative fatherhood role perceptions. Similarly, it was found that the fathers who perceived themselves at the middle or high socioeconomic level scored higher and those who perceived themselves at lower socioeconomic level scored lower. These findings overlap with those of previous studies (Poyraz, 2007; Şahin and Demiriz, 2014; Telli, 2014).

Regarding the age of being a father for the first time, it was found that those who became a father at a young age had lower scores. This finding is in line with previous studies (Poyraz, 2007; Seçer et al., 2007; Telli, 2014). In terms of family structure variable, it was found that the fathers who lived in extended family structure or those in father-child only family structure scored lower than the fathers lived in a nuclear family structure. This finding coincide with the findings of the previous studies (Poyraz, 2007; Telli, 2014). Regarding the number of children variable, it was found that the fathers who have 3-4 children scored lower than those who have 1-2 children. This finding is also in line with previous studies (Kuruçırak, 2010; Poyraz, 2007; Şahin and Demiriz, 2014). As for the age of the child variable, it was found that fathers who have 5 or 6 years old children scored lower on the scale than those who had 4 years old children. This finding does not overlap with the findings in the Ünlü Bozkurt (2018) study. She indicates no significant differences in fathers' fatherhood role perceptions by the age of children.

A statistically significant negative correlation was found between the scores of Child Parental Relationship Scale and of Fatherhood Role Perception Scale. It can be argued that when fathers' fatherhood role perceptions are 
positive, then their relationships with their 3-6 years old children are both positive and non-conflicting. The findings of the study are in line with the findings of Aksoy and Tatlı (2019).

\section{Conclusion}

According to the results of the research, the fathers' scores were varied by parental age, education level and occupation; by income and perceived socioeconomic level; by age of being father for the first time and family structure; and by the number and the age of children.

In the light of these findings, planning education programs for parents with low levels of education is suggested. In addition, for future research, expansion of the research sample including the fathers whose children do not attend to any preschool education and those who have children 0 to 6 years old and research design which may include observation and interview baseddata are suggested.

\section{Giriş}

Çocukların içinde yetiştikleri aile atmosferinin niteliği, başta ebeveynlerin olmak üzere, tüm aile fertlerinin sahip oldukları özelliklere, toplumsal yapıya ve kültüre bağlı olarak şekillenir. Modernleşme, küreselleşme ve teknolojik gelişmelere bağlı olarak ülkemizde ve dünya genelinde toplumsal yapıda ve ailenin yapısı ve işleyişinde önemli dönüşümler yaşanmıştır (Sayıl ve Selçuk, 2017; Tekin-Epik, Çiçek ve Altay, 2017; Zeybekoğlu, 2013). Modern toplumda geleneksel aile yapısı yerini modern çekirdek aileye, aile içerisindeki cinsiyete dayalı iş bölümü yerini daha eşitlikçi bir rol ve görev dağılımına ve geleneksel anne babalık kavramlan da yerini modern anne babalığa bırakmıştır (Aktürk, 2015; Bayer, 2013; Chin, Hall ve Daiches, 2011; Crespi ve Ruspini, 2015; Czymoniewicz-Klippel, 2019; Dempsey ve Hewitt, 2012; Dick, 2011; Eggebeen ve Knoester, 2001; Johansson, 2011; Lamb, 2000; Zeybekoğlu, 2013).

Modern babalık kavramının günlük hayattaki yansımaları güncel araştırmaların bulgularında kendini göstermektedir. Baba ve çocuk ilişkisini konu alan araştırmalar, babaların günümüzde geçmişe oranla daha olumlu bir babalık rolü algısına sahip olduklarını, çocukları ile daha fazla zaman geçirdiklerini, onlarla daha yakın ilişkiler kurduklarını ve çocuklarının bakım ve eğitiminde daha fazla yer aldıklarını göstermektedir (Aksoy ve Tatlı, 2019; Chin ve ark., 2011; Çatıkkaş, 2008; Gülay-Ogelman, Erol, Karaşahin ve Akyol, 
2019; Johansson, 2011; Kuruçırak, 2010; Lewis ve Lamb, 2003; MaridakiKassotaki, Antonopoulou, Olivari, Tagliabue ve Confalonieri, 2020; NelsonCoffey, Killingsworth, Layous, Cole ve Lyobomirsky, 2019; Özcebe, Küçük Biçer, Çetin, Yılmaz ve Zakirov, 2011; Poyraz, 2007; Rohner, 1998; Seçer, Çeliköz ve Yaşa, 2007; Türkoğlu ve Gültekin-Akduman, 2015a, 2015b; Telli, 2014; Ünal ve Kök, 2015; Yurtsever-Kılıçgün, 2015; Zeybekoğlu, 2013). Ancak bu tablodan geleneksel babalık anlayışının tümüyle ortadan kalktığı sonucu çıkarılmamalıdır. Nitekim, babaların çocuklarının fiziksel bakımından ziyade ilgi ve oyun aktivitelerinde katılım gösterdikleri (Kuruçırak, 2010; Lewis ve Lamb, 2003; Nelson-Coffey ve ark., 2019; Tezel-Şahin, Akıncı-Coşgun ve Aydın-Kılıç, 2017; Türkoğlu, Çeliköz ve Uslu, 2013) ve çocuklarıyla geçirdikleri zamanın, ve çocuk bakımında katılımlarının annelerin çocuklarıyla geçirdikleri zamandan ve çocuk bakımına katılımından daha az olduğu (Arabac1, 2011; Lewis ve Lamb, 2003; Maridaki-Kassotaki ve ark., 2020; Nelson-Coffey ve ark., 2019) da dikkat çekmektedir. Babalık rolü algısını incelemeye yönelik yurtiçinde yürütülen çalışmalarda çocukların (Aytekin, Artan, Bencik-Kangal, Çalışandemir ve Özkızıklı, 2016; Karakuş, Kırlığlu, Başer ve Bat1, 2013; Kuzucu, 1999), kadınların (Gedik, 2020; Ünal ve Kök, 2015; Yurtsever-Kılıçgün, 2015) ve erkeklerin (AÇEV, 2017; Kuruçırak, 2010; Poyraz, 2007; Seçer ve ark., 2007; Telli, 2014; Türkoğlu ve Gültekin-Akduman, 2015a, 2015b; Zeybekoğlu, 2013) babalık rolü algılarının hâlâ kısmen de olsa geleneksel cinsiyet rolleri çerçevesinde şekillendiğini göstermektedir. Bir diğer ifade ile, geleneksel aile yapısına özgü özellikler tümüyle yok olmamıştır (Tekin-Epik ve ark., 2017). Kökleşmiş değerler ve kültürel inançlarla şekillenmiş olan geleneksel anne babalık ve modern anne babalık uygulamaları varlıklarını eş zamanlı olarak sürdürmektedir (Sayıl ve Selçuk, 2017).

Geleneksel ve modern babalık uygulamalarının eşzamanlı varlığı sadece ülkemize özgü bir durum değildir. Crespi ve Ruspini (2015) modern toplumlarda babalardan, eşzamanlı olarak evin geçimini sağlamaları, çocuklarına rehber olmaları, onlara ilgi göstermeleri ve onların bakımında yer almaları beklendiğini ve bu çoklu rol beklentisinin erkeklik kimliği bağlamında sorunlara yol açabildiğini dile getirmektedir. Benzer şekilde, Johansson'a (2011) göre modern toplumda erkeklik ve babalık kavramları yeniden şekillenmekte ancak evin geçimini sağlama rolünü hâlâ büyük ölçüde erkekler üstlenmektedir. $\mathrm{Bu}$ nedenle erkekler yeni babalık rolünü benimserken, babalığın çocuklarla oynamak gibi keyifli yanlarını alırken, diğer tüm sorumlulukları kadına bırakma eğilimindedirler. 
$\mathrm{Bu}$ nedenle, çocuğun bakım ve eğitiminden sorumlu kişinin anne olduğu düşüncesi modern toplumda geçerliğini hâlâ korumaktadır (AÇEV, 2017; Uzun, Simsar ve Karaca, 2019). Nitekim ebeveynliği konu alan araştırmalarda ve aile eğitim uygulamalarında da hâlâ büyük ölçüde annelerin hedef alındığı görülmektedir (Mercan ve Tezel-Şahin, 2017; Tezel-Şahin ve Özyürek, 2016). Ancak baba çocuk ilişkisinin anne çocuk ilişkisinden farklı olduğu ve babanın çocuğu anneden daha farklı etkilediği bilinmektedir (Uzun ve Baran, 2019). Baba, çocuğun kişiliğinde önemli bir rol modeldir ve çocuğun gelişiminde önemli bir rol oynar (Dette-Hagenmeyer, Erzinger ve Reichle, 2014; Lamb, 2010). Babanın yoksunluğu veya ilgisizliği çocuğun kişiliğini olumsuz etkilemekte ve davranış problemlerinin ortaya çıkmasına sebep olmaktadır. Araştırmalara göre babanın çocuğun yaşantısında aktif katılımı çocuğun bilişsel, sosyal ve duygusal gelişimine ek olarak eğitim yaşantısında da önemli rol oynamaktadır (Gülay-Ogelman ve ark., 2019; Lewis ve Lamb, 2003; Rohner, 1998; Shears ve Robinson, 2005). Baba çocuk ilişkisinin çocuğun cinsiyet kimliği (Günalp, 2007; Kuzucu, 2011; Telli, 2014) ve kişilik gelişiminde (Eminoğlu, 2007; Günalp, 2007) etkili olduğu görülmektedir. Benzer şekilde Türkoğlu ve Gültekin-Akduman (2015b) araştırmalarında olumlu babalık rolü algısı ile çocuklarının sosyal beceri düzeyleri arasında pozitif yönde bir ilişki olduğunu tespit etmişlerdir. Yine, yapılan araştırmalarda babalık rolü algısı olumlu olan babaların çocukları ile daha olumlu ilişkiler kurdukları (Aksoy ve Tatlı, 2019), aile eğitim çalışmalarına daha çok katıldıkları (Şahin ve Demiriz, 2014), çocuklarının günlük ihtiyaç ve bakımlarında daha fazla sorumluluk aldıkları (Arabacı, 2011; Kuruçırak, 2010; Özcebe ve ark., 2011) saptanmıştır.

Anne ve babanın çocuğun gelişimi ve eğitimindeki rolleri birbirini tamamlar niteliktedir. Bu nedenle çocuğun hayatına ve eğitim sürecine annenin olduğu kadar babanın da katılımı desteklenmelidir (Gürşimşek, Kefi ve Girgin, 2007; Mercan ve Tezel-Şahin, 2017; Tezel-Şahin ve Özyürek, 2016; Uzun, Simsar ve Karaca, 2019). Ülkemizde baba çocuk ilişkisini inceleyen araştırmalar olsa da (Aksoy ve Tatlı, 2019; Atabey, 2017; Uyanık, Kaya, İnalKiziltepe ve Can-Yaşar, 2016; Uzun ve Baran, 2015, 2019; Uzun ve ark., 2019) annelerle yapılan araştırmalarla karşılaştırıldığında kapsam ve nicelik bakımından yeterli düzeyde değildir. Bundan hareketle, çalışmada 3-6 yaş aralığında çocuğu olan babaların babalık rolü algıları ile baba çocuk ilişkileri arasındaki ilişkinin incelenmesi amaçlanmıştır. Bu amaç kapsamında şu sorulara yanıt aranmıştır: 
1. Babaların babalık rolü algıları; anne ve babanın öğrenim düzeyine, yaşına, mesleğine, aylık gelire, algılanan sosyoekonomik düzeye, ilk baba olma yaşına, aile yapısına, sahip olunan çocuk sayısına, çocuk yaşına ve cinsiyetine göre farklılık göstermekte midir?

2. Babalık rolü algısı ile baba çocuk ilişkisi arasında bir ilişki var mıdır?

\section{Yöntem}

\section{Araştırma Modeli}

Çalışmanın amacı, okul öncesi eğitim kurumuna devam eden 3-6 yaşlarında çocuğu olan babaların babalık rolü algılarını bazı değişkenlere göre incelemek ve babaların babalık rolü algısı ile baba çocuk ilişkisi arasındaki ilişkiyi incelemektir. Araştırma ilişkisel tarama modelinde desenlemiştir. İlişkisel tarama modeli, iki ve daha fazla değişken arasındaki ilişkinin varlığını veya derecesini belirlemeyi amaçlayan bir modeldir (Karasar, 2008).

\section{Çalışma Grubu}

Araştırmanın çalışma grubunu belirlemek için Gaziantep ili Şehitkâmil ve Şahinbey merkez ilçelerindeki 299 okul öncesi eğitim kurumunun listesi çıkartılmıştır. Daha sonra, örneklemde sosyoekonomik düzey açısından çeşitlilik sağlayabilmek amacıyla bu ilçelerdeki alt, orta ve üst sosyoekonomik düzeydeki yerleşim yerleri birer küme olarak ele alınmış ve her bir kümeden yansız olarak 11 okul olmak üzere toplam 33 okul seçilmiştir. Okul öncesi dönem 3-6 yaş grubu çocukları bu okullara devam eden ve çalışmaya katılmaya gönüllü 1015 baba çalışma grubunu oluşturmuştur.

Çalışma grubunda yer alan babaların öğrenim düzeyleri lise (\%30.14), üniversite (\%24.53), ortaokul (\%21.08) ve ilkokul (\%19.31); annelerin öğrenim düzeyleri ise ortaokul (\%26.89), ilkokul (\%25.32), lise (\%24.23) ve üniversite (\%19.31) şeklinde bir dağılım göstermektedir. Babaların büyük çoğunluğunun 31-35 (\%33.60) ve 36-40 (\%29.06), annelerin ise büyük çoğunluğunun 31-35 (\%30.94) ve 26-30 (\%30.15) yaş aralığında oldukları tespit edilmiştir. Ayrıca babaların büyük çoğunluğun ilk baba olma yaşının 26-30 (\%46.90) ve 21-25 (\%36.75) yaş aralığında olduğu görülmüştür. Babaların \%3.94'ünün çalışmadı̆̆,$\% 15.46$ 'sının işçi, \%15.27'sinin memur, \%35.07'sinin özel sektör çalışanı, \%29.16'sının serbest meslek sahibi olduğu, \%1.08'inin diğer (emekli, vatman vb.) mesleklere sahip oldukları; annelerin \%83.15'inin çalışmadığı, çalışan annelerin çoğunluğunun (\%9.26) memur oldukları tespit edilmiştir. 


\section{Veri Toplama Araçları}

Araştırma verileri Kişisel Bilgi Formu, Babalık Rolü Algı Ölçeği ve Çocuk Ebeveyn İlişki Ölçeği Baba Formu aracılığıyla toplanmıştır.

\section{Kişisel Bilgi Formu}

Araştırmaya katılan babalar ve çocuklarına yönelik demografik bilgilerin elde edilmesi amacıyla araştırmacılar tarafından hazırlanmıştır. Formda anne ve baba öğrenim düzeyi, anne ve baba yaşı, anne ve baba mesleği, aylık gelir, algılanan sosyo-ekonomik düzey, ilk baba olma yaşı, aile yapısı, çocuk sayısı, çocuk yaşı ve çocuk cinsiyeti bilgilerine yönelik 14 soru yer almaktadir.

\section{Babalık Rolü Algı Ölçeği}

Kuzucu (1999) tarafından geliştirilmiş olan ölçek 5'li likert tipinde 14'ü olumlu ve 11'i olumsuz, toplam 25 maddeden oluşmaktadır. Olumsuz maddeler ters puanlanmaktadır. Ölçekten alınabilecek toplam en yüksek puan 125 ve en düşük puan 25'tir. Ölçekten yüksek puan alınması, babaların babalık rolü algısının olumlu olduğunu göstermektedir. Mevcut çalışma kapsamında ölçeğin Kuruçırak (2010) tarafından faktör analizi yeniden yapılan ve (a) Babalık Rolüne İlişkin Olumlu Algılar (12 madde), (b) Babalık Rolüne İlişkin Olumsuz Algılar (10 madde) ve (c) Çocuk Cinselliğinde Babalık Rolüne İlişkin Algılar (3 madde) olmak üzere üç boyutu olan versiyonu kullanılmıştır. Ölçeğin Cronbach Alfa katsayısı ölçek geneli için .90, Babalık Rolüne İlişkin Olumlu Algılar boyutu için .84, Babalık Rolüne İlişkin Olumsuz Algılar boyutu için .85 ve Çocuk Cinselliğinde Babalık Rolüne İlişkin Algılar boyutu için .78 olarak tespit edilmiştir (Kuruçırak, 2010). Mevcut çalışma kapsamında ölçeğin Cronbach Alfa güvenirlik katsayısı ölçek geneli için .79, Babalık Rolüne İlişkin Olumlu Algılar boyutu için .81, Babalık Rolüne İlişskin Olumsuz Algılar boyutu için .72 ve Çocuk Cinselliğinde Babalık Rolüne İlişkin Algılar boyutu için .66 olarak tespit edilmiştir. Veri toplama süreci başlamadan önce ölçeğin kullanımı için gerekli olan izin e-posta yoluyla alınmıştır.

Çocuk Ebeveyn İlişki Ölçeği Baba Formu (Child Parent Relationship Scale)

Pianta (1992) tarafından anne-baba-çocuk ilişkisini ölçmek amacı ile geliştirilmiş olan ölçek, üç alt boyut ve toplam 30 maddeden oluşmaktadır. Uzun ve Baran (2015) tarafindan ölçeğin baba formunun Türkçe uyarlaması yapılmıştır. Ölçeğin, anne ve baba formlarının orijinal ölçek ile tutarlılık gös- 
terdiği görülmüş ve Türk kültürüne uygunluğu tespit edilmiştir. Uyarlama çalışması kapsamında ölçeğin 23 maddeden ve (a) Olumlu İlişkiler (10 madde), (b) Uyumsuzluk (7 madde) ve (c) Çatışma (6 madde) olmak üzere üç alt boyuttan oluştuğu saptanmıştır: Ölçekteki maddeler 5'li likert tipindedir. Ölçekte olumlu ve olumsuz ifadeler yer almaktadır ve olumlu ifadeler tersine çevrilerek puanlanmaktadır. Ölçekten alınabilecek toplam puan en yüksek 115 ve en düşük 23'tür. Ölçekten alınan yükssek puan olumsuz ilişkiyi, düşük puan olumlu ilişkiyi göstermektedir. Ölçeğin Cronbach Alfa güvenirlik katsayısı ölçek geneli için .71, Olumlu İlişkiler boyutu için .76, Uyumsuzluk boyutu için .61, Çatışma boyutu için ise .62 olarak tespit edilmiştir (Uzun ve Baran, 2015). Mevcut çalışma kapsamında ölçeğin Cronbach Alfa güvenirlik katsayıs1 ölçek geneli için .70, Olumlu İlişkiler boyutu için .77, Uyumsuzluk boyutu için .56, Çatışma boyutu için ise .54 olarak tespit edilmiştir. Veri toplama süreci başlamadan önce ölçeğin kullanımı için gerekli olan izin e-posta yoluyla alınmıştır.

\section{Veri Toplanması ve Analizi}

Araştırma için Gaziantep İl Milli Eğitim Müdürlüğünden gerekli izinler alındıktan sonra 2018-2019 eğitim-öğretim yılının güz döneminde küme örnekleme yöntemi ile belirlenmiş olan 33 okula gidilmiş ve veri toplama araçları ögretmenler aracılığı ile toplam 1800 babaya ulaştırılmıştır. Babalara ö1çekleri doldurmaları için 10 gün süre verilmiştir. Daha sonra tekrar okullara gidilerek 1015 baba tarafindan doldurulmuş olan veri toplama araçları öğretmenler aracılığ 1 ile teslim alınmıştır. Araştırma verilerinin analizlerinde öncelikle verilerin parametrik test koşullarını sağlayıp sağlamadığını belirlemek için Kolmogorov-Smirnov Testi kullanılmış, çarpıklık ve basıklık değerleri incelenmiştir. Verilerin normallik varsayımını sağlamadığı görülmüş, bu nedenle verilerin analizinde iki grubun karşılaştırılmasında Mann-Whitney U Testi, üç ve daha fazla grubun karşıllaştırılmasında Kruskal-Wallis H Testi kullanılmıştır. Gruplar arasında anlamlı farklı1ık çıkması durumunda farklı11ğın hangi gruplar arasında olduğunu belirlemek için Mann-Whitney U Testi kullanılmıştır. Babalık Rolü Alg1 Ölçeği ve Çocuk Ebeveyn İlişki Ölçeği'nden elde edilen puanlar arasında bir ilişki olup olmadığ Analizi ile incelenmiştir.

\section{Bulgular}

Bu bölümde araştırma amacı kapsamında anne baba öğrenim düzeyi, yaş, meslek, gelir, algılanan sosyoekonomik düzey, ilk baba olma yaşı, aile 
yapısı, çocuk yaşı, çocuk sayısı, çocuk cinsiyeti değişkenlerine ilişkin elde edilen bulgulara yer verilmiştir. Bulgular tablolar halinde sunularak açıklanmiştır.

Tablo 1. Anne ve Baba Öğrenim Düzeyine Göre Babalık Rolü Algısına İlişkin Kruskal-Wallis H Testi Sonuçları

\begin{tabular}{llccccc}
\hline & & $\overline{\boldsymbol{x}}$ & Ss & K-W & $\boldsymbol{p}$ & M-W Fark \\
\hline & 1.Okur-yazar değil & 79.00 & 12.29 & & & \\
2.Okur-yazar & 92.50 & 10.09 & & & \\
Ö̈̆garenim & 3.İlkokul mezunu & 94.04 & 10.26 & & & $2,4<7$ \\
Düzeyi & 4.Ortaokul mezunu & 93.71 & 11.97 & 118.910 & $0.000 *$ & $3<4,5,6,7$ \\
& 5.Lise mezunu & 96.99 & 11.12 & & & $5<6,7$ \\
& 6.Üniversite mezunu & 102.99 & 10.14 & & & \\
& 7.Yüksek lisans-doktora & 103.62 & 9.23 & & & \\
& 1.Okur-yazar değil & 91.00 & 8.83 & & & \\
Anne & 2.Okur-yazar & 89.83 & 12.91 & & & \\
Ö̈̆grenim & 3.İlkokul mezunu & 92.97 & 11.14 & & & $1<5,6,7$ \\
Düzeyi & 4.Ortaokul mezunu & 95.49 & 11.00 & 128.861 & $0.000 *$ & $3<5,6,7$ \\
& 5.Lise mezunu & 99.95 & 10.37 & & & $4,5<6,7$ \\
& 6.Üniversite mezunu & 103.38 & 10.21 & & & \\
\hline * $p<0.05$ & 7.Yüksek lisans-doktora & 105.11 & 13.14 & & & \\
\hline
\end{tabular}

Tablo 1'de babaların Babalık Rolü Algı Ölçeği'nden aldıkları puanların anne ve baba öğrenim düzeyine göre anlamlı farklılık gösterdiği görülmekte$\operatorname{dir}(p<0.05)$. Gruplar arasında gözlenen anlamlı farklılığın, hangi gruplar arasında olduğunu belirlemek için yapılan Mann Whitney U Testi sonucuna göre, okuryazar $(\bar{x}=92.50)$ ve ortaokul mezunu ( $\bar{x}=93.71)$ olan babaların ölçekten aldıkları puanların yüksek lisans-doktora mezunu $(\bar{x}=103.62)$ babaların puanlarına göre anlamlı farklılık gösterdiği görülmektedir. İlkokul mezunu olan babaların ölçekten aldığı puanın sonraki eğitim kademelerinden mezun olan babaların puanlarından daha düşük olduğu görülmektedir. Lise mezunu olan babaların aldıkları puanın $(\bar{x}=96.99)$ üniversite $(\bar{x}=102.99)$ ve yüksek lisansdoktora mezunu ( $\bar{x}=103.99)$ babaların puanlarına göre anlamlı bir farklılık gösterdiği görülmektedir. Bu bulgular sonucunda, babaların öğrenim düzeyi arttıkça ölçekten aldıkları puanların arttığ 1 ve babalık rolü algılarının daha olumlu olduğu söylenebilir. Benzer şekilde, anne öğrenim düzeyine göre babaların Babalık Rolü Algı Ölçeği'nden aldıkları puanların anlamlı farklılık gösterdiği görülmektedir. Annelerin okuryazar olmadığ $1(\bar{x}=91.00)$, ilkokul mezunu olduğu ( $\bar{x}=92.97)$ veya ortaokul mezunu olduğu $(\bar{x}=95.49)$ ailelerdeki babaların ölçekten aldıkları puanların, annelerin lise $(\bar{x}=99.95)$, üniversite $(\bar{x}=103.38)$ veya yüksel lisans-doktora mezunu olduğu $(\bar{x}=105.11)$ ailelerdeki 
babaların puanlarına göre anlamlı bir farklılık olduğu görülmüştür. Bir diğer ifadeyle, annelerin öğrenim düzeyi arttıkça babaların ölçekten aldıkları puanların arttığı ve babalık rolü algılarının daha olumlu olduğu görülmektedir.

Tablo 2. Anne ve Baba Yaşına Göre Babalık Rolü Algısına İlişkin KruskalWallis H Testi Sonuçları

\begin{tabular}{|c|c|c|c|c|c|c|}
\hline & & $\bar{x}$ & SS & K-W & $p$ & M-W Fark \\
\hline \multirow{6}{*}{ Baba yaş } & $1.21-25$ & 92.33 & 10.48 & \multirow{6}{*}{13.703} & \multirow{6}{*}{$0.018^{*}$} & \multirow{6}{*}{$3,4,5>2$} \\
\hline & $2.26-30$ & 94.44 & 12.10 & & & \\
\hline & $3.31-35$ & 98.22 & 11.64 & & & \\
\hline & $4.36-40$ & 97.93 & 10.74 & & & \\
\hline & $5.41-45$ & 97.60 & 11.97 & & & \\
\hline & 6.46 ve üzeri & 97.37 & 10.84 & & & \\
\hline \multirow{6}{*}{ Anne yaş } & $1.21-25$ & 95.04 & 11.47 & \multirow{6}{*}{12.642} & \multirow{6}{*}{$0.027 *$} & \multirow{6}{*}{$\begin{array}{l}3,4>1 \\
3>2\end{array}$} \\
\hline & $2.26-30$ & 96.87 & 11.74 & & & \\
\hline & $3.31-35$ & 98.51 & 11.75 & & & \\
\hline & $4.36-40$ & 98.45 & 10.81 & & & \\
\hline & $5.41-45$ & 96.26 & 9.24 & & & \\
\hline & 6.46 ve üzeri & 94.85 & 13.93 & & & \\
\hline
\end{tabular}

Tablo 2'de babaların Babalık Rolü Algı Ölçeği'nden aldıkları puanların anne ve baba yaşına göre anlamlı farklılık gösterdiği görülmektedir $(p<0.05)$. Gruplar arasında gözlenen anlamlı farklılığın, hangi gruplar arasında olduğunu belirlemek için yapılan Mann Whitney U Testi sonucuna göre, 26-30 yaş aralığındaki babaların puanlarında $(\bar{x}=94.44) 31-35,36-40$ ve $41-45$ yaş aralığındaki babaların puanlarına ( $\bar{x}=98.22),(\bar{x}=97.93),(\bar{x}=97.60)$ göre anlamlı farkl1lık görülmektedir. Babaların babalık rolü algılarının daha olumsuz olduğu görülmektedir. Bir diğer ifade ile 30 yaş altında olan babaların babalık rolü algılarının 30 yaş üzerinde olan babalara göre daha olumsuz olduğu sonucuna ulaşı1mıştır. Benzer şekilde, annelerin yaşına göre babaların Babalık Rolü Alg1 Ölçeği'nden aldıkları puanların anlamlı farklılık gösterdiği görülmektedir. Annenin 21-25 yaş aralığında olduğu ailelerde babaların aldıkları puanların ( $\bar{x}=95.04)$, annenin $31-35$ ve 36-40 yaş aralığında olduğu ailelerdeki babaların puanlarına ( $\bar{x}=98.51),(\bar{x}=98.45)$ göre anlamlı farklılık gösterdiği ve babalık rolü algılarının daha olumsuz olduğu görülmektedir. Ayrıca, annenin 26-30 yaş aralığında olduğu ailelerdeki babaların puanlarının ( $\bar{x}=96.87)$, annenin 31-35 yaş aralığında olduğu ailelerdeki babaların puanlarına $(\bar{x}=98.51)$ göre anlamlı farklılık gösterdiği ve babalık rolü algılarının daha olumsuz olduğu görülmektedir. Bir diğer ifade ile annenin 30 yaş altında olduğu ailelerdeki babaların babalık rolü algılarının, annenin 30 yaş üzerinde olduğu ailelerdeki babalara göre daha olumsuz olduğu sonucuna ulaşılmıştır. 
Tablo 3. Anne ve Baba Meslek Durumuna Göre Babalık Rolü Algısına İlişkin Kruskal-Wallis H Testi Sonuçları

\begin{tabular}{|c|c|c|c|c|c|c|}
\hline & & $\bar{x}$ & ss & $\mathbf{K}-\mathbf{W}$ & $p$ & M-W Fark \\
\hline \multirow{6}{*}{$\begin{array}{l}\text { Baba } \\
\text { meslek }\end{array}$} & 1.Çalışmıyor & 92.60 & 11.86 & \multirow{6}{*}{70.800} & \multirow{6}{*}{$0.000 *$} & \multirow{6}{*}{$1,2,4,5<3$} \\
\hline & 2.İşçi & 93.21 & 12.21 & & & \\
\hline & 3.Memur & 103.61 & 10.33 & & & \\
\hline & 4.Özel sektör & 97.81 & 10.74 & & & \\
\hline & 5.Serbest meslek & 96.51 & 11.05 & & & \\
\hline & 6.Diğer & 94.45 & 14.22 & & & \\
\hline \multirow{6}{*}{$\begin{array}{l}\text { Anne } \\
\text { meslek }\end{array}$} & 1.Çalışmiyor & 96.32 & 11.31 & \multirow{6}{*}{52.191} & \multirow{6}{*}{$0.000 *$} & \multirow{6}{*}{$\begin{array}{l}1,4,5,6<3 \\
5<4\end{array}$} \\
\hline & 2.İşçi & 93.14 & 16.20 & & & \\
\hline & 3.Memur & 104.73 & 10.73 & & & \\
\hline & 4.Özel sektör & 101.20 & 10.57 & & & \\
\hline & 5.Serbest meslek & 98.07 & 8.67 & & & \\
\hline & 6.Diğer & 92.00 & . & & & \\
\hline
\end{tabular}

$* p<0.05$

Tablo 3'te babaların Babalık Rolü Algı Ölçeği'nden aldıkları puanların anne ve baba meslek durumuna göre anlamlı farklılık gösterdiği görülmekte$\operatorname{dir}(p<0.05)$. Gruplar arasında gözlenen anlamlı farklılığın, hangi gruplar arasında olduğunu belirlemek için yapılan Mann Whitney U Testi sonucuna göre, memur olan babaların $(\bar{x}=103.61)$ ölçekten aldıkları puanın diğer mesleklerdeki babaların puanlarına göre anlamlı bir farklılık olduğu ve babalık rolü algılarının daha olumlu olduğu görülmektedir. Benzer şekilde, annenin memur olduğu ailelerdeki babaların puanlarının ( $\bar{x}=104.73)$, annenin diğer meslek grubunda olduğu ailelerdeki babaların puanlarına göre anlamlı farklılık gösterdiği ve babalık rolü algılarının daha olumlu olduğu görülmektedir. Ayrıca annenin özel sektörde çalıştığı ailelerdeki babaların puanlarının ( $\bar{x}=101.20)$, annenin serbest meslek sahibi olduğu ailelerdeki babaların puanlarına ( $\bar{x}=98.07)$ göre anlamlı farklılık gösterdiği ve babalık rolü algılarının daha olumlu olduğu görülmektedir.

Tablo 4. Aylık Gelir ve Algılanan Sosyoekonomik Düzeye Göre Babalık Rolü Algısına İlişkin Kruskal-Wallis H Testi Sonuçları

\begin{tabular}{|c|c|c|c|c|c|c|}
\hline & & $\bar{x}$ & sS & K-W & $p$ & M-W Fark \\
\hline & $1.0-1000$ & 89.26 & 11.01 & \multirow{6}{*}{108.062} & \multirow{6}{*}{$0.000^{*}$} & \multirow{6}{*}{$\begin{array}{l}2<4.5 \\
3<4.5 \\
6<4\end{array}$} \\
\hline & $2.1001-3000$ & 95.10 & 11.35 & & & \\
\hline Aylık & $3.3001-5000$ & 102.08 & 9.40 & & & \\
\hline \multirow[t]{3}{*}{ Gelir } & $4.5001-7000$ & 104.89 & 9.02 & & & \\
\hline & $5.7001-9000$ & 104.61 & 10.85 & & & \\
\hline & 6.9001 ve üzeri & 98.37 & 12.36 & & & \\
\hline \multirow{3}{*}{$\begin{array}{l}\text { Algılanan Sosyo- } \\
\text { ekonomik Düzey }\end{array}$} & Alt & 92.62 & 12.08 & \multirow{3}{*}{46.559} & \multirow{3}{*}{$0.000^{*}$} & \multirow{3}{*}{$2.3>1$} \\
\hline & Orta & 98.69 & 11.03 & & & \\
\hline & Üst & 100.33 & 8.45 & & & \\
\hline
\end{tabular}

${ }^{*} p<0.05$ 
Tablo 4'te babaların Babalık Rolü Algı Ölçeği'nden aldıkları puanların aylık gelir ve algılanan sosyoekonomik düzeye göre anlamlı farklılık gösterdiği görülmektedir $(p<0.05)$. Gruplar arasında gözlenen anlamlı farklılı̆̆ın, hangi gruplar arasında olduğunu belirlemek için yapılan Mann Whitney $\mathrm{U}$ Testi sonucuna göre, 1001-3000 TL gelire sahip babaların $(\bar{x}=95.10)$ puanlarinın 3001-5000 TL ve 5001-7000 TL gelire sahip babaların $(\bar{x}=102.08)$, $(\bar{x}=104.89)$ puanlarına göre anlamlı farklılık görülmektedir. Buna ek olarak 3001-5000 TL geliri olan babaların puanlarının $(\bar{x}=102.08)$ da 5001-7000 TL ve 7001-9000 TL gelire sahip babalara $(\bar{x}=104.89),(\bar{x}=104.61)$ göre anlaml farkl11ık gösterdiğgi görülmektedir. Ve son olarak 9001 TL ve üzeri gelire sahip babaların puanlarının $(\bar{x}=98.37)$ ise 5001-7000 TL gelire sahip babalara ( $\bar{x}=104.89)$ göre anlamlı farklılık gösterdiği görülmektedir. Bu bulgudan hareketle, çok düşük ve çok yüksek gelire sahip babaların puanlarının gelir düzeyi orta seviyelerdeki babalara göre daha düşük olduğu ve babalık rolü alg1larının daha olumsuz olduğu sonucuna ulaşılabilir.

Bunlara ek olarak babaların algıladıkları sosyoekonomik düzeye göre de Babalık Rolü Algı Ölçeği'nden aldıkları puanların anlamlı farklılık gösterdiği görülmektedir. Alt sosyoekonomik düzeye sahip olduğunu algılayan babaların ( $\bar{x}=92.62$ ), kendilerini orta veya üst sosyoekonomik düzeyde algıllayan babalara ( $\bar{x}=98.69),(\bar{x}=100.33)$ göre anlamlı farklılık gösterdiği ve babalık rolü algılarının daha olumsuz olduğu görülmektedir.

Tablo 5. İlk Baba Olma Yaşı ve Aile Yapısına Göre Babalık Rolü Algısına İlişkin Kruskal-Wallis H Testi Sonuçları

\begin{tabular}{|c|c|c|c|c|c|c|}
\hline & & $\bar{x}$ & SS & $\mathbf{K}-\mathbf{W}$ & $p$ & $\begin{array}{l}\text { M-W } \\
\text { Fark }\end{array}$ \\
\hline & 1.20 ve alt1 & 93.04 & 12.04 & \multirow{6}{*}{40.746} & \multirow{6}{*}{$0.000^{*}$} & \multirow{6}{*}{$\begin{array}{l}3,4>1,2 \\
4>3\end{array}$} \\
\hline İlk & $2.21-25$ & 94.96 & 11.47 & & & \\
\hline Baba & $3.26-30$ & 98.55 & 11.35 & & & \\
\hline Olma & $4.31-35$ & 101.21 & 10.49 & & & \\
\hline \multirow[t]{2}{*}{ Yaşı } & $5.36-40$ & 97.57 & 11.52 & & & \\
\hline & $6.41-45$ & 94.00 & 8.49 & & & \\
\hline \multirow{6}{*}{$\begin{array}{l}\text { Aile } \\
\text { Yapısı }\end{array}$} & 1.Anne, baba ve çocuk(lar) & 97.86 & 11.63 & \multirow{6}{*}{14.242} & \multirow{6}{*}{$0.014^{*}$} & \multirow{6}{*}{$3,4<1$} \\
\hline & 2.Anne ve çocuk(lar) & 91.47 & 10.67 & & & \\
\hline & 3. Baba ve çocuk(lar) & 90.00 & 12.22 & & & \\
\hline & $\begin{array}{l}\text { 4.Anne, baba, çocuk (lar) ve bü- } \\
\text { yükanne-dede }\end{array}$ & 95.75 & 11.51 & & & \\
\hline & $\begin{array}{l}\text { 5.Anne, baba, çocuk (lar) ve bü- } \\
\text { yükanne-dede ve akraba }\end{array}$ & 97.36 & 9.73 & & & \\
\hline & 6.Diğer & 93.00 & 21.21 & & & \\
\hline
\end{tabular}


Tablo 5'te babaların Babalık Rolü Algı Ölçeği'nden aldıkları puanların ilk baba olma yaşı ve aile yapısına göre anlamlı farklılık gösterdiği görülmektedir $(p<0.05)$. Gruplar arasında gözlenen anlamlı farklılığın, hangi gruplar arasında olduğunu belirlemek için yapılan Mann Whitney U Testi sonucuna göre, ilk kez 26-30 ( $\bar{x}=98.55)$ ve 31-35 ( $\bar{x}=101.21)$ yaş aralığında baba olanların puanlarının 20 ve altındakiler $(\bar{x}=93.04)$ ile $21-25(\bar{x}=94.96)$ yaş aralığında baba olanlara göre anlamlı bir farklılık gösterdiği ve babalık rolü alg1larının daha olumlu olduğu görülmektedir. Ayrıca, 31-35 yaş aralığında baba olanların puanlarının ( $\bar{x}=101.21)$ ise 26-30 yaş aralığında baba olanların puanlarına $(\bar{x}=98.55)$ göre anlamlı farklılık gösterdiği ve babalık rolü algılarının daha olumlu olduğu görülmektedir.

Aile yapısına göre de babaların Babalık Rolü Algı Ölçeği’nden aldıkları puanların anlamlı farklılık gösterdiği görülmektedir. Çekirdek aile yapısında yer alan babaların puanlarının $(\bar{x}=97.86)$ diğer aile yapılarında yer alan babaların puanlarına göre anlamlı farklılık gösterdiği ve babalık rolü algılarının daha olumlu olduğu görülmektedir.

Tablo 6. Çocuk Sayısına, Yaşı ve Cinsiyetine Göre Babalık Rolü Algısına İlişkin Kruskal-Wallis H ve Mann-Whitney U Testi Sonuçları

\begin{tabular}{llccccc}
\hline & \multicolumn{1}{c}{ ss } & K-W & $\boldsymbol{p}$ & M-W Fark \\
\hline \multirow{4}{*}{ Çocuk sayısı } & 1 & 99.41 & 10.78 & & & \\
& 2 & 98.70 & 11.34 & & & \\
& 3 & 95.66 & 12.15 & 22.985 & $0.000^{*}$ & \multirow{2}{*}{$3,4<2$} \\
& 4 & 95.39 & 10.52 & & & \\
\multirow{2}{*}{ Çocuk yaşı } & 5 & 105.67 & 9.45 & & & \\
& 3 & 91.43 & 13.23 & & & \\
& 4 & 99.31 & 12.57 & \multirow{2}{*}{12.895} & $0.005^{*}$ & $5,6<4$ \\
\multirow{2}{*}{ Çocuk cinsiyeti } & 5 & 96.80 & 11.11 & & & \\
\hline${ }^{*} p<0.05$ & 6 & 97.21 & 10.93 & & \multirow{2}{*}{0.163} & \\
& Kiz & 96.92 & 11.68 & \multirow{2}{*}{121928.5} & &
\end{tabular}

Tablo 6'da babaların Babalık Rolü Algı Ölçeği'nden aldıkları puanların çocuk cinsiyetine göre anlamlı farkl11ık göstermediği $(p>0.05)$, ancak sahip olunan çocuk sayısı ve çocuğun yaşına göre anlamlı farkl11ık gösterdiği görülmektedir $(p<0.05)$. Gruplar arasında gözlenen anlamlı farklılığın, hangi gruplar arasında olduğunu belirlemek için yapılan Mann Whitney U Testi sonucuna göre, 3-4 çocuğu olan babaların $(\bar{x}=95.66)$, $(\bar{x}=95.39) 2$ çocuğu olan babalara $(\bar{x}=98.70)$ göre anlamlı farklılık gösterdiği ve babalık rolü algılarının 
daha olumsuz olduğu görülmektedir. Çocuk yaşına göre incelendiğinde çocukları 5 ve 6 yaşında olan babaların aldıkları puanların $(\bar{x}=96.80),(\bar{x}=97.21)$, çocukları 4 yaşında olan babaların aldıkları puanlara $(\bar{x}=99.31)$ göre anlamlı bir farkl11ık gösterdiği ve babalık rolü algılarının daha olumsuz olduğu görülmektedir.

Tablo 7. Babalık Rolü Algı Ölçeği ve Çocuk Ebeveyn İlişki Ölçeği Arasındaki İlişkiye Yönelik Spearman Analizi Sonuçları

\begin{tabular}{|c|c|c|c|c|c|}
\hline \multirow[b]{2}{*}{$\begin{array}{l}\text { Babalık Rolü Algı Ölçeği Alt } \\
\text { Boyutları }\end{array}$} & & \multicolumn{4}{|c|}{ Çocuk Ebeveyn İlişki Ölçeği Alt Boyutları } \\
\hline & & $\begin{array}{l}\text { Olumlu } \\
\text { İlişkiler }\end{array}$ & Uyumsuzluk & Çatışma & $\begin{array}{l}\text { Ölçek } \\
\text { Toplam } \\
\text { Puanı }\end{array}$ \\
\hline Babalık Rolüne İlişkin & $\mathrm{r}$ & $-0.377^{*}$ & -0.012 & $-0.071^{*}$ & \\
\hline Olumlu Algı & $p$ & 0.000 & 0.712 & 0.024 & \\
\hline $\begin{array}{l}\text { Babalık Rolüne İlişkin Olum- } \\
\text { suz Alg }\end{array}$ & r & $\begin{array}{l}0.004 \\
0.895\end{array}$ & $0.215^{*}$ & $0.336^{*}$ & \\
\hline $\begin{array}{l}\text { Çocuk Cinselliğinde Babalık } \\
\text { Rolüne İlişkin Algı }\end{array}$ & $\begin{array}{l}\mathrm{r} \\
p\end{array}$ & $\begin{array}{l}-0.211^{*} \\
0.000\end{array}$ & $\begin{array}{l}-0.003 \\
0.933\end{array}$ & $\begin{array}{l}-0.046 \\
0.141\end{array}$ & \\
\hline Ölçek Toplam Puanı & $\begin{array}{l}\mathrm{r} \\
p\end{array}$ & & & & $\begin{array}{l}-0.365^{*} \\
0.000\end{array}$ \\
\hline
\end{tabular}

Tablo 7'de babaların Çocuk Ebeveyn İlişki Ölçeği'nden ve Babalık Rolü Alg1 Ölçeği'nden aldıkları toplam puanlar arasında istatistiksel olarak anlamlı negatif yönlü orta düzeyde bir ilişki olduğu $(r=-0.365)$ görülmektedir. Babalık Rolü Algı Ölçeği puanı artarken Çocuk Ebeveyn İlişki Ölçeği puanı azalmaktadır. Babalık Rolü Algı Ölçeği puanlarının yüksek olması olumlu babalık rolü algısını, Çocuk Ebeveyn İlişki Ölçeği puanlarının yüksek olması olumsuz ilişkiyi göstermektedir. Bundan hareketle, olumlu babalık rolü alg1sına sahip babaların çocuklarıyla ilişkilerinin de olumlu olduğu sonucuna ulaş1labilir.

Babalık Rolü Algı Ölçeği'nin Babalık Rolüne İlişkin Olumlu Algı alt boyutu ile Çocuk Ebeveyn İlişki Ölçeği'nin Olumlu ilişkiler ( $\mathrm{r}=-0.377)$ ve Çatışma ( $(\mathrm{r}=-0.071)$ alt boyutları arasında anlamlı negatif yönde bir ilişki olduğu bulunmuştur. Yani Babalık Rolüne İlişkin Olumlu Algı alt boyutunun puanı artarken Olumlu İlişkiler ve Çatışma alt boyutlarının puanı azalmaktadır. Babalar olumlu babalık rolü algısına sahip olduklarında baba çocuk ilişkisinin de olumlu ve çatışmasız olduğu söylenebilir.

Babalık Rolü Alg1 Ölçeği'nin Babalık Rolüne İlişkin Olumsuz Alg1 alt boyutu ile Çocuk Ebeveyn İlişki Ölçeği'nin Uyumsuzluk $(r=0.215)$ ve Ça- 
tışma ( $\mathrm{r}=0.336)$ alt boyutları arasında anlamlı pozitif yönde korelasyon bulunmuştur. Yani Babalık Rolüne İlişkin Olumsuz Algı alt boyutunun puanı artarken Uyumsuz ve Çatışma alt boyutlarının puanı da artmaktadır. Babaların babalık rolü algısı olumsuz olduğunda baba çocuk ilişkisinin de uyumsuz ve çatışmalı olduğu söylenebilir.

Babalık Rolü Algı Ölçeği'nin Çocuk Cinselliğinde Babalık Rolüne İlişkin Alg1 alt boyutu ile Olumlu İlişkiler alt boyutu arasında anlamlı negatif yönde korelasyon ( $\mathrm{r}=-0.211)$ bulunmuştur. Yani Çocuk Cinselliğinde Babalık Rolüne İlişkin Algı alt boyutunun puanı artarken Olumlu İlişkiler alt boyutunun puanı azalmaktadır. Babaların çocuk cinselliği ile ilgili olarak babalık rolü algıları olumlu olduğunda baba çocuk ilişkisinin de olumlu olduğu söylenebilir.

\section{Tartışma}

Araştırma bulguları doğrultusunda çalışmaya katılan babaların babalık rolü algılarının anne ve baba öğrenim düzeyine göre farklılaştığı, öğrenim düzeyi arttıkça babaların Babalık Rolü Algı Ölçeği'nden aldıkları puanların da arttığı yani daha olumlu babalık rolü algısına sahip oldukları görülmüştür (Tablo 1). Bu bulgular alan yazındaki bulgularla örtüşmektedir (Aksoy ve Tatl1, 2019; Kuruçırak, 2010; Poyraz, 2007; Şahin ve Demiriz, 2014; Telli, 2014; Türkoğlu ve Gültekin-Akduman, 2015a, 2015b; Zeybekoğlu, 2013). Türkoğlu ve Gültekin-Akduman (2015a) 48-60 aylık çocukları olan babalarla gerçekleştirdikleri çalışmada, annelerin öğrenim düzeylerinin babaların babalık rolü algısı ile eş desteklerini etkilediği sonucuna ulaşılmıştır. Kuruçırak (2010) 4-12 ay bebekleri olan babalarla yaptığı çalışmasında elde edilen bulgularda annelerin öğrenim düzeylerinin, babalık rolü algısı ve bebek bakımına katılımlarına etki ettiği, anne öğrenim düzeyinin yüksek olmasının, babalık rolünün olumlu algılanmasında etkili olduğu tespit edilmiştir.

Baba yaşına ilişkin bulgular doğrultusunda; $31-35$ yaş ve 36-40 yaş aralığındaki babaların babalık rolü algılarının diğer yaş grubundaki babaların babalık rolü algılarına göre daha olumlu olduğu, 26-30 yaş aralığındaki babaların puanlarının 31-45 yaş aralığındaki babaların puanlarına göre anlamlı bir faklılık gösterdiği ve babalık rolü algılarının daha olumsuz olduğu sonucuna ulaşılmıştır (Tablo 2). Araştırmanın baba yaşı değişkeniyle ilgili bulgularının Seçer ve arkadaşlarının (2007) çalışmasından elde edilen bulgularla örtüşmediği görülmüştür. Söz konusu çalışmada yaşı küçük olan babaların babalığa 
yönelik algılarının yaşı büyük olan babalara göre daha yüksek olduğu sonucuna varılmıştır. Aksoy ve Tatlı (2019) çalışmasında ise babaların babalık rolü algılarında yaş değişkeninin anlamlı bir farklılığa yol açmadığı görülmüştür. Anne yaşına ilişkin bulgulara bakıldığında ise eşleri 21-25 yaş aralığındaki babalarının babalık konusunda daha olumsuz algıya sahip oldukları sonucuna varılmıştır (Tablo 2). Araştırmanın anne yaşı değişkeniyle ilgili bulguları Türkoğlu ve Gültekin-Akduman (2015b) çalışmasında elde edilen bulgularla paralellik göstermektedir. Söz konusu çalışmada anne yaşının babalık rolü alg1sında etkili olduğu tespit edilmişsir. Eşleri 25 yaş altı olan babaların babalık rolü algisının, 26 yaş üstü eşleri olan babalardan daha düşük olduğu saptanmıştır. Bireyler 20 ile 30 yaşları arasında lisans eğitiminin tamamlanması, meslek hayatına geçiş, erkekler için askerlik hizmetinin yerine getirilmesi ve evlenme gibi önemli ve strese yol açabilecek hayatî değişimler deneyimlemektedirler. Bu bağlamda düşünüldüğünde kendisi ya da eşi 30 yaşından genç olan babaların babalık rolü algısının bu değişimlerden kaynaklı stres nedeniyle daha olumsuz bir babalık rolü algısına sahip oldukları düşünülebilir.

Memur olan babaların diğer meslek gruplarına sahip babalara göre babalık konusunda daha olumlu algıya sahip oldukları sonucuna ulaşılmıştır (Tablo 3). Çalışmayan ve işçi olan babaların diğer meslek grubundaki babalara göre babalık konusunda daha olumsuz algılara sahip oldukları sonucuna ulaşılmıştır. Annenin memur olması durumunda babaların babalık konusunda daha olumlu algıya sahip oldukları sonucuna varılmıştır. Annenin çalışmadığı durumlarda babaların babalık algisı konusunda daha olumsuz algıya sahip oldukları sonucuna ulaşılmıştır. Araştırmanın baba meslek durumu değişkeniyle ilgili bulguları daha önceki çalışmalarla paralellik göstermektedir (Karadayı, 2001; Kuruçırak, 2010; Poyraz, 2007; Telli, 2014). Çalışan babaların çalışmayan babalara, memur olan babaların işçi olan babalara göre babalık rolü alg1sına ilişkin daha yüksek puan ortalamalarına sahip olduğu, babaların işinin statüsünün yüksek olmasının, babalık rolünün olumlu algılanmasında etkili olduğu sonucuna ulaşılmıştır. Baba mesleği ve öğrenim düzeyi yükseldikçe babalık rolüne ilişkin daha çağdaş görüşler sergilenmiştir. Araştırmanın anne meslek durumu değişkeniyle ilgili bulguları daha önceki çalışmaların bulgularıyla örtüşmektedir (Kuruçırak, 2010; Türkoğlu ve Gültekin-Akduman, 2015a). Anneleri çalışmayan çocukların babalarının babalık rolü algısının çalışan anneye sahip çocukların babalarından düşük olduğu, annelerin işinin statüsünün yüksek olmasının, babalık rolünün olumlu algılanmasında etkili ol- 
duğu sonucuna ulaşılmıştır. Anne ve babanın memur olduğu durumlarda babalık rolü algısının olumlu algılanmasında öğrenim düzeyinin de yüksek olmasının ve düzenli bir gelire sahip olmalarının etkili olduğu düşünülebilir.

Gelir düzeyi yüksek babaların babalık konusunda olumlu algıya, gelir düzeyi düşük olan babaların ise olumsuz algıya sahip oldukları sonucuna varılmıştır (Tablo 4). Bu bulgular daha önceki çalışmaların bulgularıyla örtüşmektedir (Poyraz, 2007; Şahin ve Demiriz, 2014; Telli, 2014). Söz konusu çalışmaların bulgularında; geliri giderine denk olan babaların babalık rolü algısının daha yüksek olduğu ve gelir düzeyi artan babaların babalık rolü algı ölçeği puanlarının da arttığı sonucuna varılmıştır. Yükseköğrenim düzeyine sahip anne babaların daha düzenli ve fazla gelir getirecek mesleklerde çalışmasının babalık rolü algısının olumlu algılanmasında rol oynadığı düşünülebilir.

Kendilerini orta sosyoekonomik düzeyde algılayan babaların puanlar1nın daha yüksek olduğu ve daha olumlu babalık algısına sahip oldukları, kendisini alt sosyoekonomik düzeyde algılayan babaların ise babalık konusunda daha olumsuz algılara sahip oldukları sonucuna varılmıştır (Tablo 4). Bu bulgular Şahin ve Demiriz (2014) 5-6 yaş çocukları olan babalarla yapılan çalışmasında elde edilen bulgularla örtüşmektedir. Söz konusu çalışmada babaların sosyoekonomik düzeyleri arttıkça babalık rolü algıları ve aile katılım çalışmalarına katılımlarının arttığı tespit edilmiştir. Algılanan sosyoekonomik düzey ile ilgili bulgular, gelir düzeyi ile ilgili bulgularla birlikte değerlendirildiğinde düşük gelir ve sosyoekonomik düzeyin babalarda geçim sıkıntısı ve strese yol açabileceği ve bu durumun da babalık rolü algılarını olumsuz etkileyebileceği düşünülebilir.

Genç yaşta baba olanların daha düşük puan aldıkları ve babalık konusunda daha olumsuz algılara sahip oldukları sonucuna varılmıştır (Tablo 5). Araştırmanın ilk baba olma yaşı değişkeniyle ilgili bulguları daha önceki ça11şmalarla paralellik göstermektedir (Poyraz, 2007; Seçer ve ark., 2007; Telli, 2014). İlk kez baba olma yaşı arttıkça babalık rolü algısının arttığı sonucuna ulaşılmıştır. İlk baba olma yaşı 31 yaş ve üstünde olanların ise babalıktan daha fazla doyum sağladıkları ve babalığa yönelik genel tutumlarının daha olumlu olduğu sonucuna ulaşılmıştır. Anne ve baba yaşı ile ilgili bulgularda olduğu gibi, ilk baba olma yaşı 30'un altında olan babaların hayatî değişimlerden kaynaklı stres nedeniyle daha olumsuz bir babalık rolü algısına sahip oldukları düşünülebilir. 
Aile yapısı bakımından incelendiğinde çekirdek aile yapısında olan babaların diğer aile yapısında yer alan babalara göre daha yüksek puan aldıkları ve daha olumlu babalık rolü algısına sahip oldukları sonucuna ulaşılmıştır (Tablo 5). Bu bulgular daha önceki çalışma bulguları ile örtüşmektedir (Poyraz, 2007; Telli, 2014). Söz konusu çalışmalarda çekirdek aile yapısına sahip babaların babalık rolü algı puan ortalamasının, geniş aile tipine sahip olan babalara göre yüksek olduğu tespit edilmiştir.

Sahip olunan çocuk sayısına ilişkin bulgular doğrultusunda; 3-4 çocuğa sahip babaların 1-2 çocuğa sahip babalardan daha düşük puan aldıkları ve babalık konusunda olumsuz algıya sahip oldukları sonucuna ulaşılmıştır (Tablo 6). Araştırmanın çocuk sayısı değişkeniyle ilgili bulguları daha önceki çalışmalarla paralellik göstermektedir (Kuruçırak, 2010; Poyraz, 2007; Şahin ve Demiriz, 2014). Tek çocuklu babaların babalık rolü algı ölçeği puanlarının daha yüksek olduğu ve babaların sahip oldukları çocuk sayısının az olmasının, babalık rolünün olumlu algılanmasında etkili olduğu sonucuna ulaşılmıştır.

Çocukları 5 ve 6 yaşında olan babaların ölçekten çocukları 4 yaşında olan babalardan daha düşük puan aldıkları ve babalık konusunda daha olumsuz algıya sahip oldukları saptanmıştır (Tablo 6). Araştırmanın çocuk yaşı değişkeniyle ilgili bulguları Ünlü-Bozkurt (2018) çalışmasındaki bulgularla örtüşmemektedir. Söz konusu çalışmada babaların babalık rolü algılarının çocuk yaşına göre farklılaşmadığı sonucuna ulaşılmıştır.

Çalışmaya katılan babaların babalık rolü algılarının çocuk cinsiyetine göre farklılaşmadığı görülmüştür (Tablo 6). İlgili alan yazında çocuk cinsiyeti ile ilgili bulgularda tutarlılık bulunmamaktadır. Poyraz (2007) çalışmasında erkek çocuğa sahip babaların babalık rolü algı ölçeği puanlarının yüksek olduğu ve olumlu algıya sahip oldukları sonucuna ulaşılmıştır. Buna karşın çocuk cinsiyetinin babaların babalık rolü algılarında farklılığa yol açmadığını belirten araştırmalar da mevcuttur (Aksoy ve Tatl1, 2019; Şahin ve Demiriz, 2014; Ünlü-Bozkurt, 2018).

Babaların Çocuk Ebeveyn İlişki Ölçeğinden ve Babalık Rolü Algı Ö1çeğinden aldıkları toplam puanlar arasında istatistiksel olarak anlamlı negatif yönlü orta düzeyde bir ilişki olduğu görülmüş ve olumlu babalık rolü algısına sahip babaların çocuklarıyla ilişkilerinin de olumlu olduğu sonucuna ulaşı1mıştır (Tablo 7). Ölçeklerin alt boyutları arasındaki ilişki incelendiğinde, olumlu babalık rolü algısına sahip olduklarında babaların çocuklarıyla ilişkisinin de olumlu ve çatışmasız olduğu, babalık rolü algısı olumsuz olduğunda 
baba çocuk ilişkisinin de uyumsuz ve çatışmalı olduğu ve babaların çocuk cinselliği ile ilgili babalık rolü algıları olumlu olduğunda baba çocuk ilişkisinin de olumlu olduğu sonucuna ulaşılmıştır. Araştırma bulguları Aksoy ve Tatlı (2019) çalışmasında elde edilen bulgularla paralellik göstermektedir.

\section{Sonuç ve Öneriler}

Araştırmada kendisinin ve/veya eşinin öğrenim düzeyi yüksek olan, yaşı ve/veya ilk baba olma yaşı 30 ve üzerinde olan, kendisi ve/veya eşi memur olan, gelir düzeyi düşük olmayan ve 1-2 çocuğu olan babaların babalık rolü algılarının yüksek yani olumlu olduğu ve çocukları ile ilişkilerinin de olumlu ve çatışmasız olduğu görülmüştür. Bu bulgular çalışmanın giriş bölümünde sunulan alanyazın 1şı̆̆ında genel olarak değerlendirildiğinde iki önemli sonuç ortaya çıkmaktadır. İlk olarak bu bulgular ilgili alanyazındaki geleneksel babalıktan modern babalık anlayışına doğru bir dönüşüm olduğu tespitini (Aktürk, 2015; Bayer, 2013; Chin ve ark., 2011; Crespi ve Ruspini, 2015; Czymoniewicz-Klippel, 2019; Dempsey ve Hewitt, 2012; Dick, 2011; Eggebeen ve Knoester, 2001; Johansson, 2011; Lamb, 2000; Zeybekoğlu, 2013) doğrular niteliktedir. Çalışma grubunun Gaziantep ili sınırlarında yaşayan babalardan oluştuğu dikkate alındığında bu sonuç oldukça önem arz etmektedir. Gaziantep ili kent nüfusunun demografik ve sosyoekonomik özelliklerini inceledikleri çalışmada Geniş ve Adaş (2011), kentte genç nüfus yoğunluğuna rağmen öğrenim düzeyinin düşük ve öğrenim düzeyinde cinsiyetler arasında kadınlar aleyhinde eşitsizliğin olduğunu, yoksulluğun yüksek olduğu kentte işsizlik oranının yüksek ve kadın istihdamının çok düşük olduğunu, hane halkı sayısının ortalama sekiz olduğu kentte geleneksel kültür ve iş bölümünün yaygın olduğunu bulmuşlardır. Böylesi bir sosyal yapı içerisinde yaşayan babaların bir kısmının dahi olsa olumlu babalık rolü algısına sahip olmaları modern babalığa doğru dönüşümün etkisini doğrular niteliktedir.

İkinci olarak araştırma bulguları babalık rolü algılarının hâlâ kısmen de olsa geleneksel cinsiyet rolleri çerçevesinde şekillendiğini (AÇEV, 2017; Aytekin ve ark., 2016; Gedik, 2020; Karakuş ve ark., 2013; Kuzucu, 1999; Kuruçırak, 2010; Poyraz, 2007; Seçer ve ark., 2007; Telli, 2014; Türkoğlu ve Gültekin-Akduman, 2015a, 2015b; Ünal ve Kök, 2015; Yurtsever-Kılıçgün, 2015; Zeybekoğlu, 2013) ve bu nedenle modern babalık algısının geleneksel babalık algısı ile eş zamanlı olarak varlığını sürdürdüğü (Sayıl ve Selçuk, 2017) ve geleneksel babalık algısının tümüyle ortadan kalkmadığı (Tekin- 
Epik ve ark., 2017) tespitini de doğrular niteliktedir. Nitekim araştırmada kendisinin ve/veya eşinin öğrenim düzeyi düşük olan, yaşı ve/veya ilk baba olma yaş1 30 yaşın altında olan, kendisi ve/veya eşi çalışmayan ya da işçi olan, gelir düzeyi düşük olan ve 3 ve daha fazla sayıda çocuğu olan babaların babalık rolü algılarının düşük yani olumsuz olduğu ve çocukları ile ilişkilerinin de olumsuz ve çatışmalı olduğu görülmüştür.

Araştırma sonuçlarına göre anne ve baba öğrenim düzeyi arttıkça babaların daha olumlu babalık algısına sahip oldukları görülmüştür. Olumlu babalık rolü algısına sahip babaların çocuklarıyla daha olumlu ilişkiler kurdukları dikkate alındığında eşinin ya da kendisinin öğrenim düzeyi düşük olan babaların olumlu babalık rolü algısı edinmeleri ve çocuklarıyla olumlu ilişkiler kurabilmeleri için aile eğitim programları ile desteklenmeleri önerilebilir.

Araştırmanın örneklemi çocukları bir okul öncesi eğitim kurumuna devam eden babalarla sınırlıdır. Babalık rolü algısı konusunda ileride yürütülecek araştırmalarda çocukları bir okul öncesi eğitim kurumuna devam etmeyen babaların da örnekleme dâhil edilmesi önerilebilir. Bu şekilde çocukları okul öncesi eğitim hizmetlerinden yararlanan ve yararlanmayan babaların babalık rolü algıları karşılaştırmalı olarak incelenebilir.

Çalışmaya katılan babaların çocuklarının 3-6 yaş grubunda olması araştırmanın bir diğer sınırlılığını teşkil etmektedir. Araştırma bulgularına göre babaların babalık rolü algısının çocuk yaşına göre farklılaştığı görülmektedir. Ancak mevcut araştırmanın örneklemi 3-6 yaş aralığı ile sınırlı olduğu için babaların daha küçük yaştaki çocukları ile ilişkileri kapsamında babalık rollerini nasıl algıladıkları incelenememiştir. İleride yürütülecek araştırmalarda örneklemin 0-6 yaş grubu çocuğu olan babaları kapsayacak şekilde genişletilmesi önerilebilir.

Araştırmada elde edilen veriler babaların Babalık Rolü Algı Ölçeğinde yer alan sorulara verdikleri yanıtlarla sınırlıdır. İleride yürütülecek araştırmalarda gözlem temelli verilerin de araştırma sürecine dâhil edilmesi önerilebilir. $\mathrm{Bu}$ suretle, babaların babalık rolü algılarının günlük hayat pratiklerine yansımalarının nasıl olduğu, çocukları ile ne sıklıkla ve ne tür etkinliklerde yer aldıkları, çocukların bakımı ile ilgili olarak ne tür sorumlulukları üstlendikleri de incelenebilir.

Araştırma verilerinin babaların Babalık Rolü Algı Ölçeği'nde yer alan sorulara verdikleri yanıtlarla sınırlı olması nedeni ile bu araştırma kapsamında 
babaların babalık rolü algılarının bazı değişkenlere göre farklılaşıp farklılaşmadığı incelenebilmiş ancak babaların babalık rolü algılarında etkili inanç ve değerlerinin neler olduğu incelenememiştir. İleride yürütülecek araştırmalarda ölçek verilerine ek olarak babalarla derinlemesine görüşmeye dayalı verilerin de sürece dâhil edilmesi önerilebilir. Bu suretle, babalık rolü algısı düşük ve yüksek olan babaların babalık rolü algılarında etkili değer ve inançların neler olduğu incelenebilir.

Çalışmada her ne kadar birbirinden bağımsız olarak ele alınmış olsa da gerçekte öğrenim düzeyi, yaş, gelir, meslek, çocuk sayısı gibi değişkenler birbirinden bağımsız değildirler. İleri öğrenim düzeyi, evlilik ve çocuk sahibi olma yaşının ertelenmesi, daha yüksek statüde ve düzenli gelir sağlayan mesleklerde çalışma ve daha az sayıda çocuk sahibi olma ile ilişkilidir. Öğrenim düzeyi yüksek bireylerin toplumsal cinsiyet rollerine yönelik daha eşitlikçi algılara sahip oldukları da bilinmektedir (Altuntaş ve Altunova, 2015; Çiçek ve Çopur, 2018; Savaş, 2018). Olumlu toplumsal cinsiyet algısı beraberinde bireylerin cinsiyete dayalı geleneksel aile yapısına özgü anne babalık rollerinden uzaklaşmalarını ve kendi hayat gerçeklerine uygun daha eşitlikçi roller üstlenmelerini mümkün kılmaktadır. Bu bağlamda düşünüldüğünde toplumsal cinsiyet eşitsizliğini ortadan kaldırmaya yönelik politikaların geliştirilmesi sureti ile özellikle de düşük öğrenim düzeyine sahip ailelerdeki babaların daha olumlu babalık rolüne sahip olmaları ve çocukları ile daha olumlu ilişkiler kurmaları desteklenebilir.

\section{Kaynakça}

AÇEV (2017). Türkiye'de ilgili babalık ve belirleyicileri: Özet araştırma raporu. https://acev.org/wpcontent/uploads/2018/01/BabalikArastirmasiAnaRapor.16.10.17.web_.pdf.

Aksoy, A. B. ve Tatlı, S. (2019). Okul öncesi dönem çocuğu olan babaların çocuklarıyla olan ilişkileri ile babalık rolü algıları arasındaki ilişkinin bazı değişkenler açısından incelenmesi. Çankırı Karatekin Üniversitesi Sosyal Bilimler Enstitüsü Dergisi, 10, 1-22.

Aktürk, F. M. (2015). Çocukları okul öncesi eğitime devam eden (5 yaş grubu) ebeveynlerin ana baba tutumlarının farklı değişsenler açısından incelenmesi. Yayımlanmamış yüksek lisans tezi, Selçuk Üniversitesi Sosyal Bilimler Enstitüsü.

Altuntaş, O. ve Altunova, H. H. (2015). Toplumsal cinsiyet algısı ile sosyo-ekonomik değişkenler arasındaki ilişkinin belirlenmesi. Turkish Studies, 10(6), 83-100.

Arabac1, N. (2011). Anne-Baba-Çocuk Illetişimini Değerlendirme Aracının (ABÇIDA) geliştirilmesi ve anne-baba-çocuk iletişiminin bazı değişkenler açısından incelenmesi. Yayımlanmamış doktora tezi, Gazi Üniversitesi Eğitim Bilimleri Enstitüsü. 
Atabey, D. (2017). Bazı değişkenlere göre erken çocukluk döneminde okul-baba ilişkisi. Uluslararası Sosyal Araştırmalar Dergisi, 10(52), 721-729.

Aytekin, Ç., Artan, İ., Bencik Kangal, S., Çalışandemir, F. ve Özkızıklı, S. (2016). Çocukların anne babalarına yönelik algılarının incelenmesi. Mehmet Akif Ersoy Üniversitesi Ĕ̈itim Fakültesi Dergisi, 38, 168-188.

Bayer, A. (2013). Değişen toplumsal yapıda aile. Şırnak Üniversitesi Ilahiyat Fakültesi Dergisi, 4(8), 101-129.

Chin, R., Hall, P. ve Daiches, A. (2011). Fathers' experiences of their transition to fatherhood: A metasynthesis. Journal of Reproductive and Infant Psychology, 29(1), 4-18.

Crespi, I. ve Ruspini, E. (2015). Transition to fatherhood: New perspectives in the global context of changing men's identities. International Review of Sociology, 25(3), 353-358.

Czymoniewicz-Klippel, M. T. (2019). Parenting in the context of globalization and acculturation: Perspectives of mothers and fathers in Siem Reap, Cambodia. Childhood, 26(4), 525-539.

Çatıkkaş, K. T. (2008). Okul öncesi eğitime babaların katılım düzeyleri ile ilgili değişkenlerin incelenmesi. Yayımlanmamış yüksek lisans tezi, Yeditepe Üniversitesi Sosyal Bilimler Enstitüsü.

Çiçek, B. ve Çopur, Z. (2018). Bireylerin kadınların çalışmasına ve toplumsal cinsiyet rollerine ilişkin tutumları. International Journal of Eurasian Education and Culture, 4, 1-21.

Dempsey, D. ve Hewitt, B. (2012). Fatherhood in the $21^{\text {st }}$ century. Journal of Family Studies, 18(2-3), 98-102.

Dette-Hagenmeyer, D. E., Erzinger, A. B. ve Reichle, B. (2014). The changing role of the father in the family. European Journal of Developmental Psychology, 11(2), 129-135.

Dick, G. L. (2011). The changing role of fatherhood: The father as a provider of selfobject functions. Psychoanalytic Social Work, 18(2), 107-125.

Eggebeen, D. J. ve Knoester, C. (2001). Does fatherhood matter for men? Journal of Marriage and Family, 63, 381-393.

Eminoğlu, B. (2007). Dört-beş yaş çocuklarının sosyal davranışları ile ebeveyn davranışları arasındaki ilişkinin incelenmesi. Yayımlanmamış yüksek lisans tezi, Gazi Üniversitesi Eğitim Bilimleri Enstitüsü.

Gedik, E. (2020). The relationship between father and child in daily life narratives of female academicians with children in pre-school period. Kültür ve Iletişim, 23(45), 118-141.

Geniş, Ş. ve Adas, E. B. (2011). Gaziantep kent nüfusunun demografik ve sosyoekonomik yapısı: Saha araştırmasından notlar. Gaziantep Üniversitesi Sosyal Bilimler Dergisi, 10(1), 293-321.

Gülay-Ogelman, H., Erol, A., Karaşahin, N. ve Akyol, M. (2019). Fathers and their young children's self-perception, levels of being liked by their peers and prosocial behaviours. International Journal of Academic Research in Education, $5(1), 31-42$.

Günalp, A. (2007). Farklı anne baba tutumlarının okul öncesi eğitim çağındaki çocukların özgüven duygusunun gelişimine etkisi. Yayımlanmamış yüksek lisans tezi, Selçuk Üniversitesi Sosyal Bilimler Enstitüsü. 
Gürşimşek, I., Kefi, S. ve Girgin, G. (2007). Okul öncesi eğitime babaların katılım düzeyi ile ilişkili değişkenlerin incelenmesi. Hacettepe Üniversitesi Ĕ̆itim Fakültesi Dergisi, 33, 181-191.

Johansson, T. (2011). Fatherhood in transition: paternity leave and changing masculinities. Journal of Family Communication, 11(3), 165-180.

Karadayı, F. (2001). Gençlerin babalık rolüne ilişkin tutumları, kendi babalarının davranışı ve sosyo demografik faktörlerle ilişkisi. Çukurova Üniversitesi Sosyal Bilimler Enstitüsü Dergisi, 8(8), 165-188.

Karakuş, Ö., Kırlığlu, M., Başer, D. ve Batı, B. (2013). Yetiştirme yurdunda kalmakta olan ergenlerin anne baba algıları: Nitel bir çalışma. Toplum ve Sosyal Hizmet Dergisi, 24(2), 123-143.

Karasar, N. (2008). Bilimsel araştırma yöntemleri. Ankara: Nobel Yayın.

Kuruçırak, Ş. (2010). 4-12 aylık bebeği olan babaların, babalık rolü algısı ile bebek bakımına katılımı arasındaki ilişki. Yayımlanmamış yüksek lisans tezi, Akdeniz Üniversitesi Sağlık Bilimleri Enstitüsü.

Kuzucu, Y. (1999). Babalarıyla çatışma düzeyi yüksek ve düşük olan ergenlerin ve babalarının babalık rolüne ilişkin algılarının karşılaştırılması. Yayımlanmamış yüksek lisans tezi, Ankara Üniversitesi Sosyal Bilimler Enstitüsü.

Kuzucu, Y. (2011). Değişen babalık rolü ve çocuk gelişimine etkisi. Türk Psikolojik Danışma ve Rehberlik Dergisi, 4(35), 79-91.

Lamb, M. E. (2000). The history of research on father involvement. Marriage and Family Review, 29(2-3), 23-42.

Lamb, M. E. (2010). How do fathers influence children's development? Let me count the ways. M. Lamb, (Ed.), The role of the father in child development (5. bask1) içinde (1-26). Hoboken, NJ: Wiley.

Lewis, C. ve Lamb, M. E. (2003). Fathers' influences on children's development: Evidence from two-parent families. European Journal of Psychology of Education, 18(2), 211-228.

Maridaki-Kassotaki, K., Antonopoulou, K., Olivari, M. G., Tagliabue, S. ve Confalonieri, E. (2020). Examining fatherhood in Greece and Italy. Journal of Family Studies, 26(1), 1-15.

Mercan, Z. ve Tezel Şahin, F. (2017). Babalık rolü ve farklı kültürlerde babalık rolü algısı. Uluslararası Erken Çocukluk Eğitimi Çalışmaları Dergisi, 2(2), 1-10.

Nelson-Coffey, S. K., Killingsworth, M., Layous, K., Cole, S. W. ve Lyubomirsky, S. (2019). Parenthood is associated with greater well-being for fathers than mothers. Personality and Social Psychology Bulletin, 45(9), 1378-1390.

Özcebe, H., Küçük Biçer, B., Çetin, E., Yılmaz, M., ve Zakirov, F. (2011). 0-10 yaş aralığında çocuğu olan babaların çocuk sağlığı ve bakımındaki rolleri. Çocuk Să̆lı̆̆ ve Hastalıklarl Dergisi, 54(2), 70-78.

Poyraz, M. (2007). Babaların babalık rolünü algllamalarıyla kendi ebeveynlerinin tutumları arasındaki ilişkinin incelenmesi. Yayımlanmamış yüksek lisans tezi, Gazi Üniversitesi Eğitim Bilimleri Enstitüsü.

Rohner, R. P. (1998). Father love and child development: History and current evidence. Current Directions in Psychological Science, 7(5), 157-161.

Savaş, G. (2018). Türkiye'de yaşayan bireylerin toplumsal cinsiyet eşit(siz)liği algısı. Akdeniz Kadın Çalışmaları ve Toplumsal Cinsiyet Dergisi, 1(2), 101-121. 
Sayıl, M. ve Selçuk, B. (2017). Türkiye'de ana babalık çalışmalarına bakış. M. Sayıl ve B. Selçuk, (Ed.), Ana babalık: kuram ve araştırma içinde (15-18). İstanbul: Koç Üniversitesi Yayınları.

Seçer, Z., Çeliköz, N. ve Yaşa, S. (2007). Bazı kişisel özelliklerine göre okul öncesi eğitim kurumlarına devam eden çocukların babalarının babalığa yönelik tutumları. Selçuk Üniversitesi Sosyal Bilimler Enstitüsü Dergisi, 18, 425-438.

Shears, J. ve Robinson, J. (2005). Fathering attitudes and practices: influences on children's development. Child Care in Practice, 11(1), 63-79.

Şahin, H. ve Demiriz, S. (2014). Beş altı yaşında çocuğu olan babaların, babalık rolünü algılamaları ile aile katılım çalışmalarını gerçekleştirmeleri arasındaki ilişkinin incelenmesi. Türkiye Sosyal Araştırmalar Dergisi, 18(1), 273-294.

Tekin Epik, M., Çiçek, Ö. ve Altay, S. (2017). Bir sosyal politika aracı olarak tarihsel süreçte ailenin değişen/değişmeyen rolleri. Sosyal Politika Çalışmaları Dergisi, 17(38), 35-57.

Telli, A. A. (2014). 3-6 yaş grubu çocuğu olan babaların babalık rolü algısı ve etkileyen faktörlerin belirlenmesi. Yayımlanmamış yüksek lisans tezi, Atatürk Üniversitesi Sağlık Bilimleri Enstitüsü.

Tezel-Şahin, F., Akıncı-Coşgun, A. ve Aydın-Kılıç, Z. N. (2017). Babaların çocuklarıyla vakit geçirme durumlarına ilişkin görüşlerinin incelenmesi. Gazi Eğitim Fakültesi Dergisi, 37(1), 319-343.

Tezel-Şahin, F. ve Özyürek, A. (2016). Anne baba eğitimi ve aile katılımı. Ankara: İstatistik Dünyası.

Türkoğlu, B., Çeliköz, N. ve Uslu, M. (2013). 3-6 yaş aralığında çocuğu olan babaların nitelikli zaman algılarına dair görüşleri. Ĕgitim ve Öğretim Araştırmaları Dergisi, 2(2), 54-71.

Türkoğlu, D. ve Gültekin-Akduman, G. (2015a). Okul öncesi dönem çocuğu olan babaların babalık rolü algısı ile eş destek düzeyleri arasındaki ilişkinin incelenmesi. Uluslararası Sosyal Araştırmalar Dergisi, 8(38), 761-772.

Türkoğlu, D. ve Gültekin-Akduman, G. (2015b). Okul öncesi dönem çocuğu olan babaların babalık rolü algısı ile çocuklarının sosyal becerileri arasındaki ilişkinin incelenmesi. Karadeniz Sosyal Bilimler Dergisi, 1(7, Hüseyin Hüsnü Tekışık Özel Sayıs1), 223-240.

Uyanık, Ö., Kaya, Ü. Ü., İnal-Kızıltepe, G., ve Can-Yaşar, M. (2016). Çocuğu okul öncesi eğitim kurumuna devam eden babaların çocukları ile olan ilişkilerinin incelenmesi. Kuramsal Eğitimbilim Dergisi, 9(4), 515-531.

Uzun, H. ve Baran, G. (2015). Çocuk ebeveyn ilişki ölçeğinin okul öncesi dönemde çocuğu olan babalar için geçerlik ve güvenirlik çalışması. Uluslararası Ĕ̆itim Bilimleri Dergisi, 2(3), 30-40.

Uzun, H. ve Baran, G. (2019). Babaların okul öncesi dönemdeki çocuklarıyla ilişkisinin bazı değişkenlere göre incelenmesi. Mersin Üniversitesi Eğitim Fakültesi Dergisi, 15(1), 47-60.

Uzun, H., Simsar, A. ve Karaca, H. N. (2019). Türkiye'de erken çocukluk döneminde baba çocuk ilişkisi konusunda hazırlanan lisansüstü tezlerin incelenmesi. $E$ Kafkas Eğitim Araştırmaları Dergisi, 6(2), 1-8.

Ünal, F. ve Kök, E. E. (2015). 0-6 yaş çocuğu olan ebeveynlerin babalık rolüne ilişkin görüşleri. International Journal of Social Sciences and Education Research, 1(4), 1383-1396. 
Ünlü-Bozkurt, H. (2018). Okul öncesi dönemde çocuğu olan anne ve babaların anababalık algısı. Yayımlanmamış yüksek lisans tezi, Hacettepe Üniversitesi Eğitim Bilimleri Enstitüsü.

Yurtsever-Kılıçgün, M. (2015, Mayıs). Çocuk haklarına yönelik ebeveyn tutumları ile ebeveynlik rolleri arasındaki ilişki. Uluslararası Katılımlı III. Çocuk Gelişimi ve Eğitimi Kongresi'nde sunulmuş bildiri, Hacettepe Üniversitesi, Ankara.

Zeybekoğlu, Ö. (2013). Günümüzde erkeklerin gözünden babalık ve aile. Mediterranean Journal of Humanities, 3(2), 297-328. 